\title{
既設トンネル周辺岩盤の調査手法と設計への応用 \\ INVESTIGATION METHOD FOR ROCK MASS AROUND PRE-EXISTING TUNNELS AND ITS APPLICATION IN DESIGN
}

\author{
谷口 親 平*・亀和田俊一**・米田 裕 樹*** \\ By Sinpei TANIGUCHI, Shunichi KAMEWADA and Hiroki YONEDA
}

\begin{abstract}
In this paper, the outline of the BIP system, suitable investigation method for rock mass around pre-existing tunnels and its application in design are discussed.

The BIP system is effective in evaluating 1) the scale of voids. 2) loosening zones behind tunnels and 3) direction of dominating cracks and altered zones.

This method will prove efficient in design and construction especially when 2) and 3) are specified. This will enable the suggestion of the area to be pre-bolted and the length and direction of bolts necessary to avoid further spread of loosening zones during the investigation stage.
\end{abstract}

Keywords : investigation method for rock mass, bore-hole TV, image processing technology

\section{1. まえがき}

近年, 交通量の増加に伴い既設道路トンネルの改築工 事の需要が多くなっている.

改築工事に先だち, 既設トンネルの変状箇所の状態, 規模およびその原因についての調査とその対応策が重要 となる。

最近，ボーリング孔を利用して，岩盤状況を調査する 研究・開発が注目されつつある ${ }^{1) \sim 4}$ が, 著者らは事前調 査のボーリング孔の孔壁を連続撮影し，孔壁展開画像を 処理する手法 (BIPS; Borehole Image Processing System, 孔壁展開画像システム) を開発5)し，既設トン ネル背面の調査を行った.

その結果，BIPS は以下に示す事項に有効であること が判明した。

既設トンネル背面の，(1)空洞の規模，(2)ゆるみ領域の 推定, (3)亀裂の卓越する方向と変状部分の推定.

特に，(2)，(3)が判断できれば，ゆるみ領域を拡大させ ないための補強対策およびその施工範囲を調査の段階で 示唆することができる.

* 正会員 パシフィックコンサルタンツ(株) 西日本事業本 部第一技術部 ( $\bar{\top} 541$ 大阪市中央区南本町 2-5-9)

** (株) Raax 代表取締役 (テ101 札愰市北区北 14 条西 $2 丁$ 目)

*** 正会員 パシフィックコンサルタンツ(株) 西日本事業本 部第一技術部（テ541 大阪市中央区南本町 2-5-9)
本論文では, BIPS の概要と調査例およびその補強対 策例について報告する.

\section{BIPS の概要}

BIPS (Borehole Image Processing System) はボー リング孔の孔壁を連続撮影し, 地質解析を行うことが可 能な装置である。

これまで一般に使われてきたボアホールテレビは視野 が狭いために, 孔壁の連続性の判断および亀裂の方向の 判断を行うためには，写真の貼り合せ合成に多大な時間 亡労力を要したが, BIPS はこれらの欠点を補っている. 装置の特徴は以下のとおりである.

(1) 現地において孔壁の展開画像亡全周生画像を同時 にリアルタイムでみることができる.

(2) ゾンデの降下速度を任意に調節し（0～ $50 \mathrm{~m} / \mathrm{h})$ 一点に停止させて長時間の観察(地下水の湧出なざ) を行うことができる.

（3）パソコンの CRT 上で展開画像を任意縮尺でみる ことができ, 地質解析 (地層面, 不連続面の走向傾 斜や開口幅の測定など）ができる.

(4) 孔壁画像の三次元表示ができる.

本装置のシステム構成は図一1のとおりである.

なお，本装置はゾンデ部分をロッドに固定し，孔内に 送り出すことで鉛直以外に任意の方向に推進された孔に 


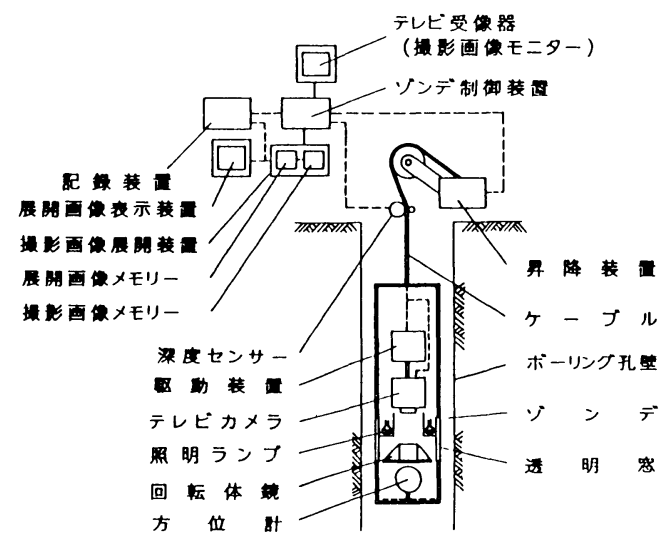

図一1 BIPS のシステム構成

適用が可能である。

したがって，既設トンネル内での背面の岩盤に向かっ て掘進されたボーリング孔を使って，さまざまな情報を 定方向に得ることが可能である.

\section{3. 既設トンネル調查の考え方}

既設トンネルの調查項目は以下のとおりである.

(1) 既設トンネル覆工巻厚

(2) 既設トンネル背面の空洞の規模

(3) 既設トンネル背面ゆるみ領域の推定

(4) 亀裂の卓越する方向と変状部分の推定

おのおのの目的を以下に述べる.

(1) 既設トンネル覆工巻厚

既設トンネルの覆工に薄い箇所があれば，拡大時のゆ るみが既設トンネル覆工に載荷された場合, 崩壊する危 険性もありこの巻厚測定は施工法の検討のうえで重要な 要素となる.

(2) 既設トンネル背面の空洞の規模

既設トンネルと地山との空隙は拡大時にさらにゆるみ を拡大させる要因ともなり,その規模を知る必要があり, 場合によっては地山と空洞部の注入計画に反映できる.

(3) 既設トンネル背面のゆるみ領域の推定

拡大施工の最も重要な点は既設トンネルのゆるみ領域 をそれ以上に拡大させないことである。

既設トンネルのゆるみ領域を推定できれば，その領域 外の新鮮岩にロックボルトを定着させ, 拡大時のゆるみ を最少限に押えることができる.

(4) 亀裂の卓越する方向と変状部分の推定

亀裂の卓越する方向および変状が推定できれば，補強 対策の施工範囲およびその方向を判定することができ る.

現況交通止が可能な場合, これらの補強対策が既設卜 ンネルから事前に行うことができる点は, 拡大施工の有

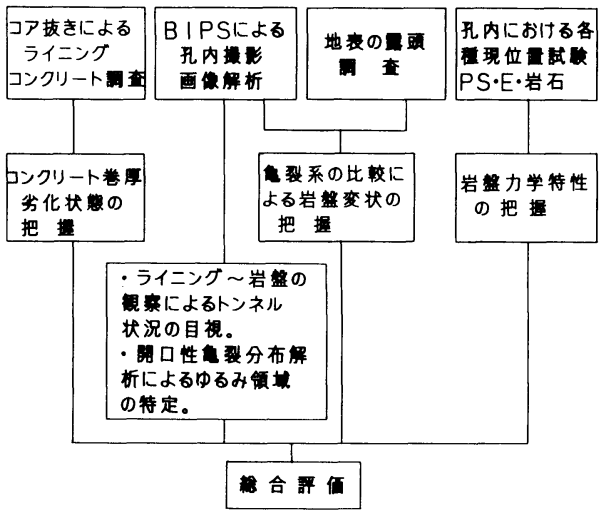

図一2 既設トンネル拡大の現況調查フロー

利な点であろう。

図一2に調査フローを示す。

\section{4. 調 査 例}

\section{（1）空洞の規模}

写真一1 はHトンネルにおける観察例で，No. 2 孔に おいてはライニングコンクリート背面に約 $35 \mathrm{~cm}$ の空 洞部分が存在し，また，岩盤の一部がブロック状に完全 に浮石状となっているのが観察される.

一方，Oトンネルにおいては，写真一 2 に示すように $1.1 \mathrm{~m}$ の空洞部が存在することが判明した.

\section{（2）ゆるみ領域の推定}

図一3(b) は，Oトンネルにおけるトンネル背面の 岩盤に発達する開口亀裂を, トンネル背面からの距離と 開口の大きさで整理して示したものである。

これによれば開口性 1 2 $\mathrm{mm}$ 程度の亀裂がほぼ均等 な密度で分布しているのに対し，8〜10 $\mathrm{mm}$ 程度の大き い開口性を示す亀裂が内空近傍に集中して分布してお り，これらがトンネル掘削とその後の経過に伴って発生 したものであることを示唆している.

図一3(a ) は（b ）において任意の点を基準点とし， ここからトンネル内空に至る区間の開口亀裂の開口量を 累積して示したものである.

本図において割れ目の開口度は展開画像上で読み取っ た最大部分とし, 割れ目の方向性に無関係に開口量を累 積している.

したがって内空側で示される累積ゆるみ量は直接孔壁 の変位量を示すのではなく, 岩盤内に存在するゆるみ量 の大小を示す指標としてとらえられる.

ここに示される累積ゆるみ量曲線は, 基準点加ら内空 側に向けて，ゆるみ量が増加する傾向を示しており，均 等な密度で分布する開口亀裂によってゆるい傾きのリニ アな直線で示される自然地山のもつバックグラウンドの 


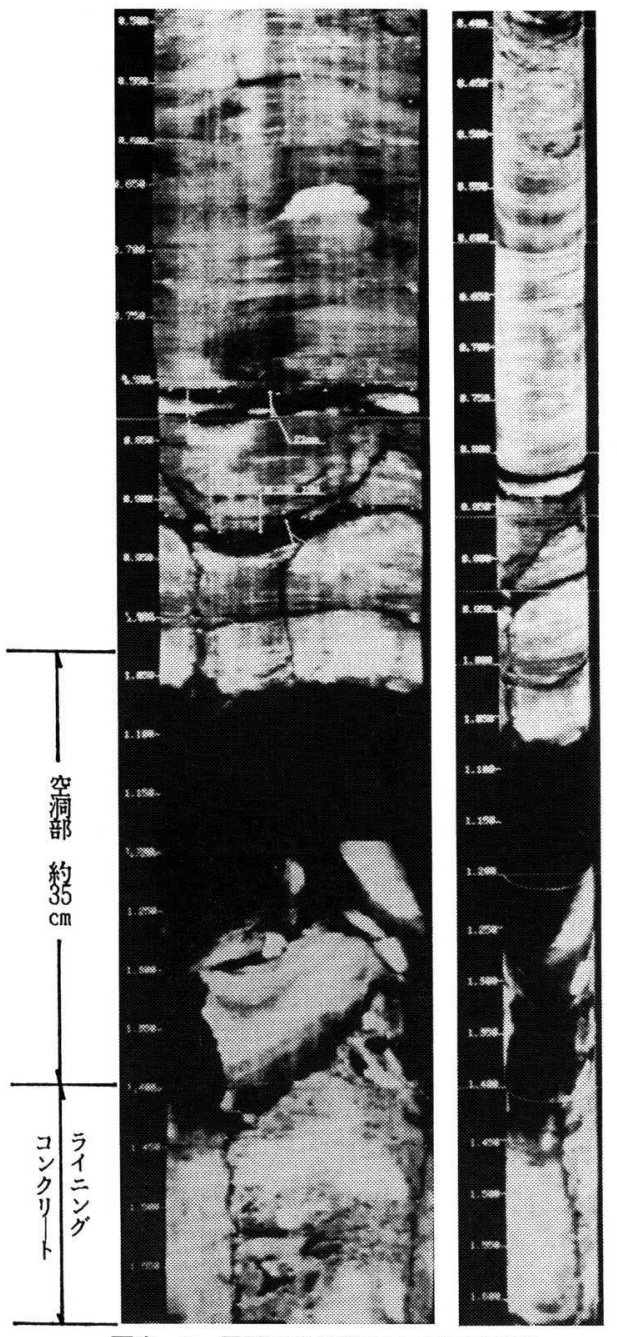

写真一1 展開画像処理による空洞規模

(Hトンネル)

部分と, 内空側近傍でトンネル掘削によって発生したと 考えられる開口亀裂によって示されるゆるみ量が急に増 加する部分が認められる.

いま（a）において自然地山のバックグラウンドの量 を(1)とすれば, 本地点における岩盤ゆるみの発生区間は, 岩盤の掘削面から約 $1.6 \mathrm{~m}$ の範囲であり，この区間の 累積ゆるみ量は $41 \mathrm{~mm}$ となる。

このゆるみ量を壁面に直交する方向への押し出し量と 考えると， $1.5 \%$ のひずみ量を示すことになる.

これは地山変形係数とひずみの関係から切羽の安定を 示した図一 $4^{6)}$ からも切羽が不安定領域に位置 $(E=$ $1300 \mathrm{kgf} / \mathrm{cm}^{2}$ とひずみ=1.5\%の交点）することを示 している.

（3）亀裂の方向と変状部分

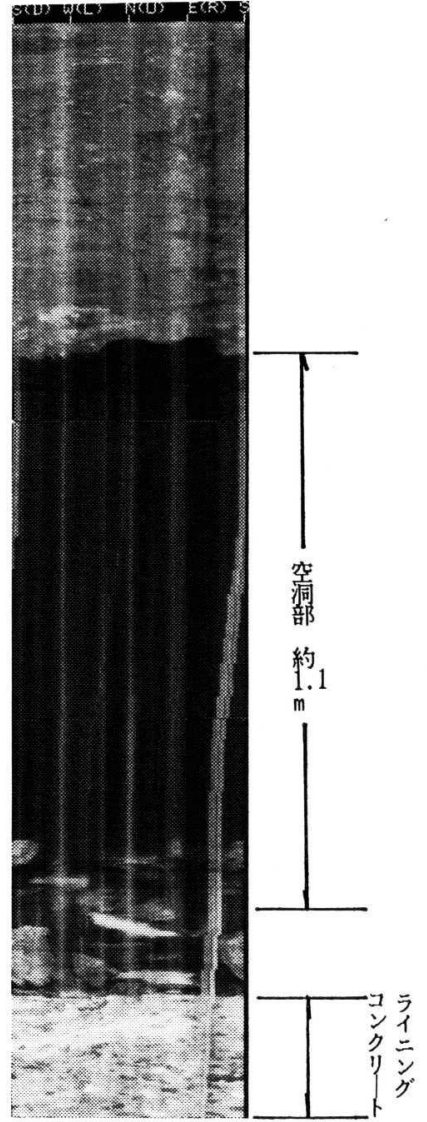

写真一2 展開画像処理による空洞規模

(Oトンネル)

Oトンネル地点の地質は三波川帯に属する結晶片岩 からなり，図一5にBIPS 測定結果を総合して亀裂系の シュミットダイヤグラムを示したものである.

露頭においては，亀裂の走向傾斜はあらゆる方向に散 在しており，明瞭な傾向を示していない。

これに対して, No. 1 孔では $\mathrm{N}_{40^{\circ}} \sim 60^{\circ} \mathrm{E}$ の走向を 示す片理群とこれに平行な走向を示し, $10^{\circ} \sim 20^{\circ} \mathrm{SE}$ に傾斜する亀裂の発達が顕著である.

これは, 卓越する片理面の傾斜と直交する $70^{\circ} \sim 80^{\circ}$ NW の方向が変状しやすく, トンネル横断面に対して 天端より右肩部にかけての $\left(\theta \doteqdot 30^{\circ}\right)$ 部分を示すもの と考えられる.

\section{BIPS による調査結果と設計への応用}

Oトンネルにおいては, BIPS によって表一1 に示す 事実が判明した.

補強対策としては, 事前にロックボルトによる補強と エアーモルタルによる背面注入を行いゆるみ領域の拡大 

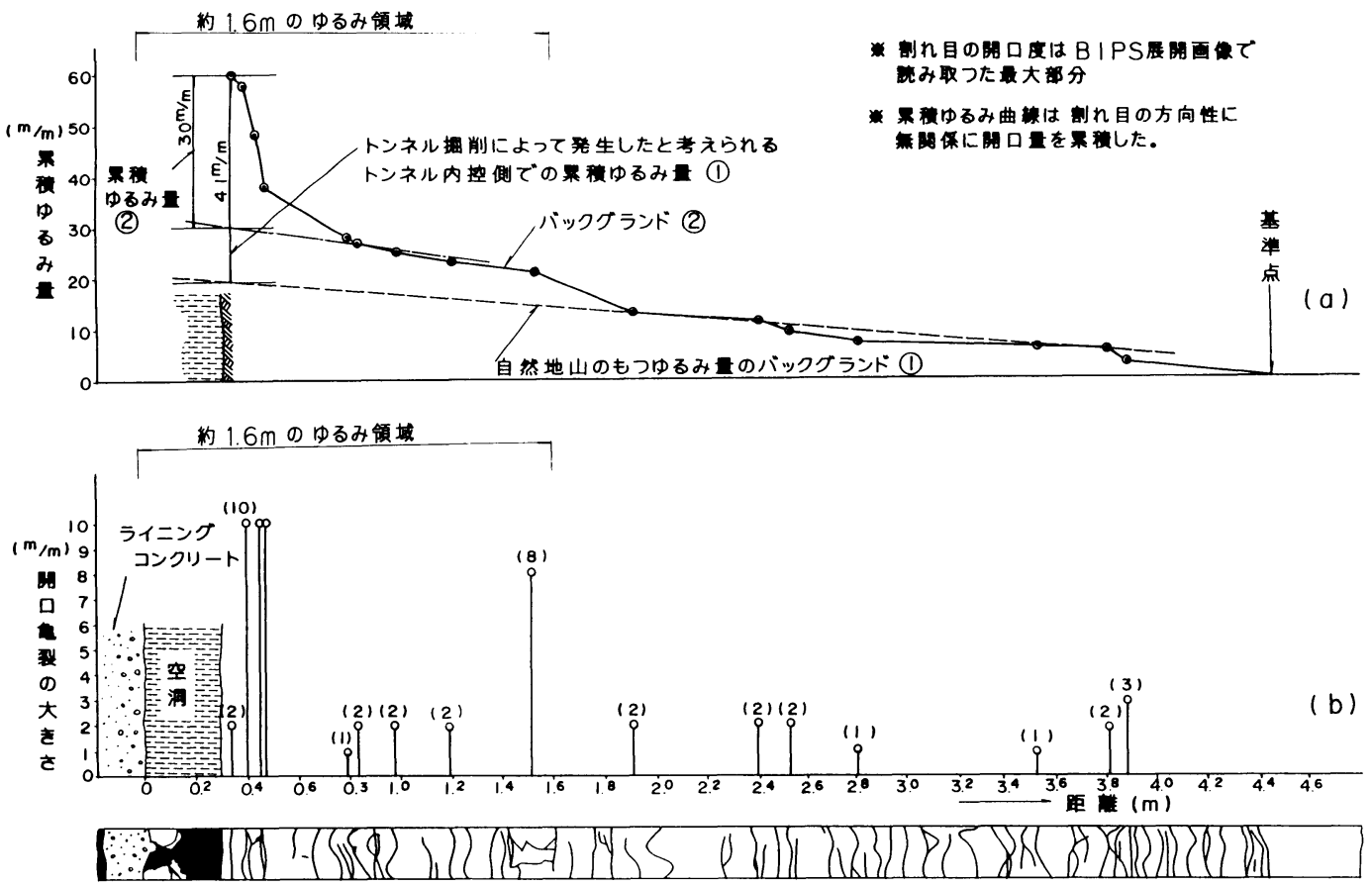

図一3 開口量裂の分布と累積ゆるみ量の推定図

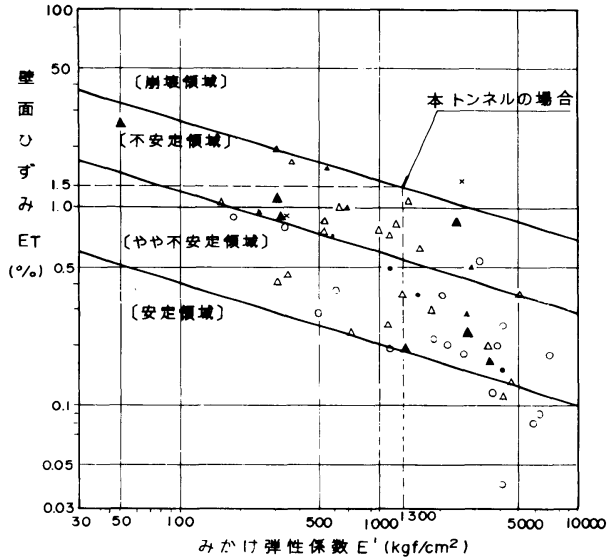

図一4 NATM におけるみかけ弾性係数 $\left(E^{\prime}\right)$ と壁面ひずみ $\left(E_{T}\right)$ との関係

を防ぐものとした

これら補強対策の応用については，表一1右欄に示し， おのおのについて説明を加える.

（1）卓越する片理面の走向(トンネル軸線に対して) 卓越する片理面のトンネル軸線に対する走向傾斜は $\mathrm{N} 10^{\circ} \sim 60^{\circ} \mathrm{E}$ および $10^{\circ} \sim 20^{\circ} \mathrm{SE}$ に集中し, トンネル 軸線 $\left(\mathrm{N} 50^{\circ} \mathrm{E}\right)$ に対しほぼ平行であることが判明した. この傾向はNo. 1 孔のダイヤグラムで䫓著に表われるた め, ロックボルトの打設範囲は始点側から中央部にかけ
表一1 BIPS による調査結果と補強対策への応用

\begin{tabular}{|c|c|c|}
\hline 調查項日 & $\begin{array}{l}\text { B I P S } \text { による } \\
\text { 調 查 結 果 } \\
\end{array}$ & 補強対策への忘用 \\
\hline $\begin{array}{l}\text { 1) 卓越する片理面 } \\
\text { の走向(トンネ } \\
\text { ル軸線に対して) }\end{array}$ & $\begin{array}{c}\text { トンネル軸線に対 } \\
\text { してはほ平行する } \\
\text { 凶間がN.1 孔で額 } \\
\text { 著（始点側〜 } \\
\text { 中央部） }\end{array}$ & $\begin{array}{l}\text { ロックボルト打設範 } \\
\text { 井の判断 } \\
\text { (始点〜中央部 ) }\end{array}$ \\
\hline $\begin{array}{l}\text { 2) 卓越する片理面 } \\
\text { の傾斜 (トンネ } \\
\text { ル横断面に対し } \\
\text { て) }\end{array}$ & $\begin{array}{l}\text { トンネル横断面に } \\
\text { 対して天端からた } \\
\text { 简部に } 10 \sim 20^{\circ} \\
\text { で緩傾斜 }\end{array}$ & $\begin{array}{l}\text { ロックボルト打設の } \\
\text { 主方向の判断 }\end{array}$ \\
\hline 3)ゆるみ領域 & $\begin{array}{l}\text { 既設トンネル背面 } \\
1.6 \mathrm{~m} \text { までゆるみ } \\
\text { 领域が你在する。 }\end{array}$ & $\begin{array}{l}\text { ロックボルトの言さ } \\
\text { の判断 }\end{array}$ \\
\hline 4) 空 润 の 規 模 & $\begin{array}{l}\text { - 始点側坑[ ( N } \\
1 \text { 孔 )で約 } 40 \mathrm{~cm} \\
\text { - 中央部 約 } 10 \sim \\
15 \mathrm{~cm} \text { (トンネル } \\
\text { 天端〜楯部) } \\
\text { - 終点側坑口で約 } \\
1.1 \mathrm{~m}\end{array}$ & 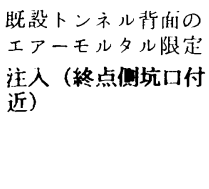 \\
\hline
\end{tabular}

ての区間に必要であると判断した。

（2）卓越する片理面の傾斜（トンネル横断面に対し 乙)

片理面の傾斜が $10^{\circ} \sim 20^{\circ} \mathrm{SE}$ であるため, ロックボ ルトはそれに直交する $70^{\circ} \sim 80^{\circ} \mathrm{NW}$ の方向に有効であ ると考えられる.

これは,トンネル横断面に対して天端より右肩部にか けて $\left(\theta \doteqdot 30^{\circ}\right)$ の方向になる.

また，開口亀裂がその他の区間でも $10^{\circ} \sim 20^{\circ} \mathrm{SE}$ 方 
（）地裁に分布する不遟繶面 (地表踏查結果より)

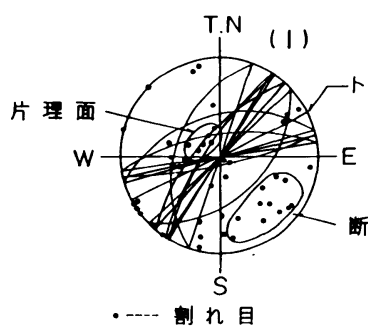

（2）BIPS测定結果による 不連繶面

(1) NO.1 孔

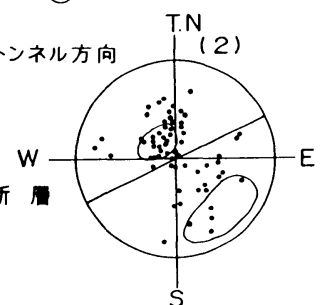

図-5

5 ○トンネルに
片 理 面

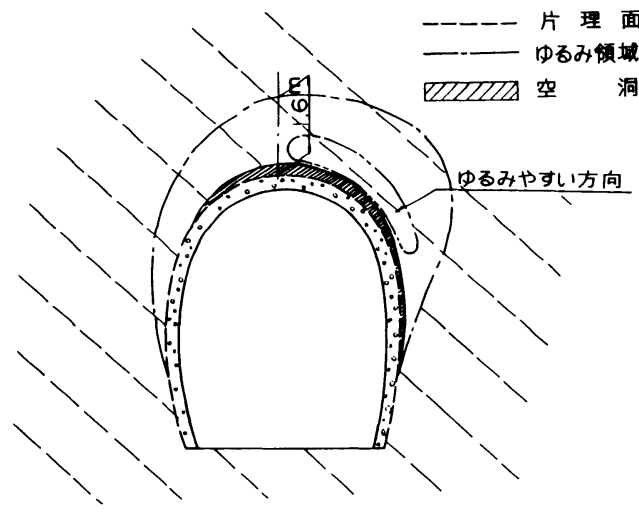

図一6 片理面の卓越する方向とゆるみ領域

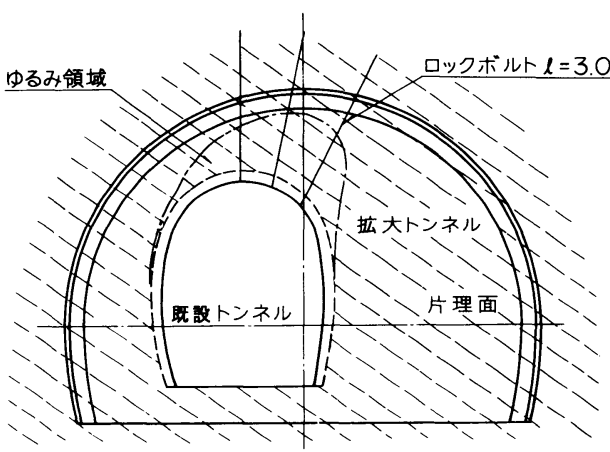

図一8 補強ボルトの長さと施工範囲

向に集中していることが明確になった．

これらの調査結果からロックボルト打設の主方向は天 端より右肩部 $30^{\circ}$ の方向が妥当であると判断した。

\section{(3) るみ領域}

開口㫣裂を累積ゆるみ量として考えると特に背面 1.6 $\mathrm{m}$ の地点からゆるみ量が急に増加し，それ以深の岩盤 では少なくなっている事実から，ゆるみ領域が $1.6 \mathrm{~m}$ であると判断した。

よって，ロックボルトの長さを新鮮岩盤に $1 \mathrm{~m}$ 程度 定着させ, $l=3.0 \mathrm{~m}$ とし, ゆるみ領域の拡大を防ぐも
草起する片理面の走向倾鈄

(2) NO.2 孔

W

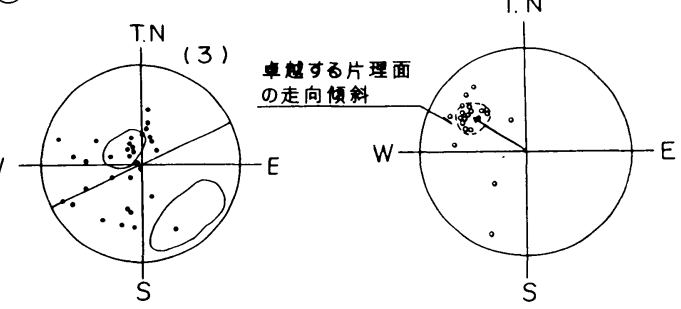

走向一 $\mathrm{N} 40^{\circ} \sim 60^{\circ} \mathrm{E}$ 傾斜一 $10^{\circ} \sim 20^{\circ} \mathrm{SE}$

内空近彺の片理面
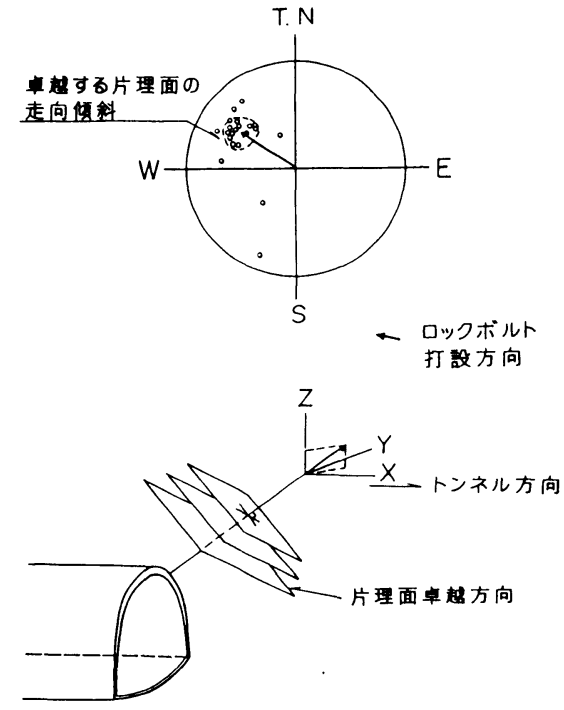

図一7绳裂解析とロックボルト打設方向の模式図

のとした

\section{（4）空洞の規模}

終点側坑口では約 $1.1 \mathrm{~m}$ の大規模な空洞が存在する ため，エアーモルタルを充填することで覆工と地山とを 一体化させ，応力集中を避けるものとした。

\section{6. まとめと今後の課題}

拡大施工に先だち，既設トンネル背面の岩盤状況を BIPS で画像処理した結果，卓越した亀裂の走向傾斜， およびゆるみ領域の推定に有効であることが判明した。 その調査結果から補強対策の施工範囲と方向が調査の段 階で示唆できた。

以下に調査例のまとめと今後の課題について述べる.

（1）卓越した片理面の走向は $\mathrm{N} 40^{\circ} \sim 60^{\circ} \mathrm{E}$ に集中 し, トンネル軸線 $\left(\mathrm{N} 50^{\circ} \mathrm{E}\right)$ に対し, ほぼ平行である. この傾向はNo.1 孔のダイヤグラムで顕著であるため, 
補強対策の施工範囲が特定できた.

（2）卓越した片理面の傾斜は $10^{\circ} \sim 20^{\circ} \mathrm{SE}$ である ためそれに直交する $70^{\circ} \sim 80^{\circ} \mathrm{NE}$ の方向が変状しやす いと判断された.

これは, トンネル横断面に対するロックボルトの主方 向が判断できたことになる.

（3）開口亀裂の大きさをトンネル背面からの距離 で, 累積ゆるみ曲線として表現した場合, 特に $1.6 \mathrm{~m}$ の地点が急に増加する位置であると読み取れる.

この調査結果から背面のゆるみ領域は $1.6 \mathrm{~m}$ と把握 できた.

よって, ロックボルトの長さを新鮮岩部に $1 \mathrm{~m}$ 程度 定着させ, $l=3.0 \mathrm{~m}$ とし, ゆるみ領域の拡大を防ぐも のとした。

今後, 既設トンネルの拡大施工時, および近接施工時 にBIPSを用いることによって, 事前と事後の地山状 況の変化を比較すれば, 補強対策の妥当性の確認ができ る.

さらに，最近注目を浴びている地下大規模断面（地下 換気所, 石油備蓄基地等) 補強対策への応用が可能とな ろう.
これらの調査例と補強対策への応用について研究し, 機会があれば発表したいと考えている。

\section{参 考 文 献}

1）たとえば, 㐘地・水戸・黒田：節理分布の確率統計学的 評価に基づく節理性岩盤のモデル化, 第 7 回岩の力学国 内シンポジウム講演論文集, pp. 151〜157, 1987.

2）たとえば, 吉中・吉田・藤田：岩盤不連続面の方向性に 関する分布特性の評価とそのブロック理論への応用, 第 7 回岩の力学国内シンポジウム講演論文集, pp. 145 150, 1987.

3）たとえば, 大野・小島：フラクタルを考慮した岩盤割れ 目の寸法評価と透水性, 第 7 回岩の力学国内シンポジウ ム講演論文集, pp. 157 167, 1987.

4）たとえば, 谷本・畠・刚谷：孔内載荷試験結果の評価に 関する考察, 岩盤力学に関するシンポジウム講演論文集, pp. 6〜10, 1982.

5）谷口・亀和田・米田・国分：既設トンネル老朽度の謂査 手法の開発, 岩盤力学に関するシンポジウム講演論文集, pp. 191 195, 1989.

6) 土木学会関西支部：都市トンネルへの NATM の適用, pp. 18, 1987.

(1989.2.21 - 受付) 